\title{
The Correlations Between Mentors' Leadership Competencies And The Functions Performed By The Mentors
}

\author{
Aelita Skarbaliene, PhD \\ Klaipeda University, Lithuania
}

doi: 10.19044/esj.2016.v12n8p1 URL:http://dx.doi.org/10.19044/esj.2016.v12n8p1

\begin{abstract}
Although it is acknowledged positive mentor's influence to mentee's development, but not many researches were done to find personal and professional qualities that makes mentor to perform his or her functions better. The lack of such researches encouraged to carry out the research and to determine if the mentor's leadership competencies have an effect on performance of mentor's functions, i.e. to determine the correlations between the mentor's leadership competencies and the quality of mentor's functions performed. It was determined average strong, statistically significant linear positive correlation between mentor's leadership competences and the quality of mentor's functions performed. This correlation means that if mentor has stronger leadership competences, he or she performs mentor's functions better.
\end{abstract}

Keywords: Leadership; mentorship; mentors' functions

N. Gehrke as far back as in 1991 proposed that in pursuance of more professionals to take the role of leaders the systematic attitude to this question is necessary and provided arguments that it is needed to begin preparing students for the leadership at high school. As claimed by A. W. Astin at al. (2000), high schools play an extremely significant role in creating and forming the quality of leadership in the contemporary society, whereas the leadership is one of the most important results of high education. It has been determined by scientific researches that each person has the potential for leadership while students in study years could improve and improve factually their leadership skills (Zimmerman-Oster, Burkhardt, 1999; Pascarella, Terenzini, 2005), whereas when leadership abilities improve, the social activeness of young people increases, energetic and positive character traits develop, and the participation in academic activity as 
well as in the activity of student organisations increases (Fertman, Van Linden, 1999; Benson, Saito, 2000; Komives, Owen, et al., 2005; et al.).

C. M. Wells (2010) reasons the idea that in order to develop the leadership of teachers the systematic activity is required, whereas the input of schools into it, that is to form the mindset and train teachers for the role of leaders, is fundamental.

The importance of education of leadership competencies is recognized not only by scientists, but also by some high schools. For instance, some universities appreciate the significance of leadership and name such training of students that would enable them to participate successfully in the process of leadership and encourage the society growth (Cress, Astin, Zimmerman-Oster, Burkhardt, 2001; Roberts, 2003). Recently, the leadership training in the study programmes of high schools as well as in non-formal activities has become a tendency and is recognised as substantial regardless of what profession students are going to acquire (Riggio, Ciulla, Sorenson, 2003; Schwartz, Axtman, Freeman, 1998; Paccaud, Weihofen, Nocera, 2011; Uno, Zakariasen, 2010).

As the tendency of students' leadership education and development increased, institutions of higher education faced with the problem how to develop students' leadership competences. It has to be stated that after the importance of leadership education and development was highlighted, some of the higher schools scheduled leadership subject into the study programs. But leadership theorists and practitioners indicates that students' leadership skills and competences have not changed so much. It is reasoned mainly due to the big gap between leadership theory and practice; i.e. students get theoretical leadership knowledge and simply do not know how to use it in practice (Middlehurst, 2008; Lindsay et al, 2009; etc.).

After summing up the research on training of the leadership competencies in the study programmes of high schools three strategies recommended by the authors for the formal and non-formal leadership training were distinguished: (1) the promotion of involvement training of the leadership competencies into curricula; (2) the promotion of practical activity and (3) non-formal training of the leadership competencies (Skarbalienè, 2013).

Practical activities when students have a possibility to be leaders, i.e. the practical work during lectures, study practice, internships, activity in various communities, etc. is called especially meaningful strategy by leadership theorists and practitioners. The significance of it is motivated by the statement: the leadership is learned by acting in it. According to V. Šernas (2005), practical activity helps to transform profession knowledge into living knowledge by independent purposeful applying of knowledge in practical activity of a professional. Speaking about practical activities, the 
idea of mentor involvement into the process of training of students' leadership competencies is raised (Skarbalienè, 2015). The influence of mentoring on better leadership achievements of students is based on scientific research as well. It is thought that mentors can help students to create relations with high school, motivate to involve more actively into academic, artistic, sport activity as well as the activity of student and youth organisations, learn new skills and behaviour, and realize the particularity of a chosen profession (Day, 2001; Brungardt et al., 2006; Dugan, Komives, 2007; Scandura, 2011; et al.).

S. Long (2002) states that mentor is a smart and reliable teacher or consultant. The origins of the term go back to ancient times, when Homer told the story about the Troy war in his epic drama "Odyssey”. When going to the war Odyssey left his son to the friend, called Mentor. The modern understanding of mentorship is associated with the book of D. Levinson (1978, cit. Thibodeaux, Hays-Thomas, 2005) called “The Seasons of a Man’s Life". The role of a mentorship to the professional development is described in it. Many interpretations of mentorship concept can be found in the literature. G. Alerd et al. (2000), M. J. Lankau, T. A. Scandura (2002) describe mentorship as a process during which a more experienced and qualified person teaches, encourages, advises, supports and maintains good relations with the less skilled and/or experienced person (mentee) at his own example. This process is intended for the person's accelerated professional and / or personal development. Mentee's professional and personal development as a main mentor's function is stated in many authors' papers. J. E. Girves, Y. Zepeda and J. K. Gwathmey (2005) say that the function of personal support (also called psychosocial support) includes role modelling, exhortation, consulting and collegial nature in the process of mentorship. And the function associated with the mentee's professional carrier includes teaching, instructing and consulting. It is proven also that consulting is important both for personal and professional development. M. Ladišienè, O. Monkevičienè (2007) also stresses the importance of consulting. They argue that consulting is very much needed, because it helps to recognize person himself in a various activities and motivates professional development. In addition to these functions, mentor is also an advisor, a moral backer and source of information, and an ideal to which a student can align (Yahner, Goodstein, 2012; Omatsu, 2012).

In the context of this work we use the definition of mentor by A. J. Van (2002) that says that mentor is an experienced teacher, who foster a student during the study practice, who establish and maintain informal contact with him or her, who shapes student's education, professional and personal behaviour, who gives the assistance, supervision and the feedback, 
who helps in planning the professional carrier, who assess mentee's competency and progress.

According to M. Barkauskaitė and P. Pečiulaitienè (2007) study practice is the period when the final provisions of the student's professional career and one's approach to the rights, duties and responsibilities are building. The research by K. Stankevičienè and O. Monkevičienè (2007) confirmed that students acquire better skills during a study practice when with a mentor than without it. Authors argue that mentor is needed to student as a model; mentor can share his professional experience, and practising at the organization enables the student to develop professional skills in the presence of experienced professionals in a given social environment, rather than in isolation.

T. A. Scandura et al (1996) and D. Clutterbuck (2004) think that the biggest benefit student gets during study practise is the knowledge mentor share. Authors say that the knowledge strengthen mentee's confidence. And that is the reason why student bravely takes the activities that affect his later career; and the combination potential of confidence helps feel professional (expert) and achieve even better results. Even more completely benefits of the study practice and mentorship are explained by $\mathrm{M}$. Barkauskaite et al (2007). It is said that after a study practice students change their attitudes towards the profession chosen - they find it more difficult, more responsible, the understand the need for better professional, social and intercultural competency; and it is proven that mentor has big influence to this change of the attitude. These insights match with A. Pollard's (2006) opinions about main aspects and tendencies of mentorship. He indicates these tendencies:

1. Professional recognition grows together with understanding of competencies required for the profession.

2. Since much attention is paid to the study practice during the study process, the supervision of the mentor is very important in the context of high professional standards and passing knowledge from generation to generation.

3. Mentorship is very flexible way of education and development, so professional qualification can be acquired during the study practice.

The importance of transmission of knowledge and special skills is emphasized by L. Cummins (2004). She accents that mentorship gives the opportunity for young professionals communicate with the "real" professionals, makes them feel stronger and influences more successful development.

So mentor who supervise student during the study practice monitors mentee's activities, chose education styles, professional and personal behaviour, transfer professional experience and knowledge, tries shapes student's attitude toward the profession, rights, duties and responsibilities. 
According to D. Nasvytienè and M. Pileckaite (2004) such an activity influences students and motivates them. And even more - it has a positive effect on the institutional culture and student education and training system.

Although it is acknowledged positive mentor's influence to mentee's development, but not many researches were done to find personal and professional qualities that makes mentor to perform his or her functions better. Idea of B. S. Posner (2009) can be mentioned. He states that when person gets mentor's role, most often understands that as a good evaluation of the work done. This evaluation creates motivation share own experience and competences with the mentee. The lack of such researches encouraged to carry out the research and to determine if the mentor's leadership competencies have an effect on performance of mentor's functions, i.e. to determine the correlations between the mentor's leadership competencies and the quality of mentor's functions performed.

So empirical research was planned, applying quantitative research strategy and relevant data analysis methods.

The described research has two samples. The first sample includes full-time undergraduate students of the first-cycle teacher training programmes of Lithuanian higher education institutions, and the second sample includes teaching practice supervisors-mentors of these students. Since both groups of respondents are interrelated (their participation in the survey is pair-based), it was decided that the starting point of the sample should be students. Reliable research results have been expected to be obtained randomly, in accordance with the territorial principle, selecting several higher education institutions and questioning all the students who have agreed to participate in the survey. Thus, the universities of Klaipeda, Siauliai and Lithuanian University of Education Sciences, as well as the colleges of Kaunas, Panevezys and Vilnius were invited and agreed to participate in the research. 82.74 percent of the representatives of the analysed general set study in these higher education institutions. Each student was given a set of three questionnaires (pre-test and post-test questionnaires and a questionnaire for practice mentor). 536 sets of questionnaires have been collected. Thus, the research included total of 54.75 percent of the representatives of the total research population.

Two questionnaires were made as well.

The questionnaire for mentors comprises the questions about the expression of leadership competencies. Questions are based on the Teacher Leader Model Standards, developed by the USA Teacher Leadership Exploratory Consortium. The questionnaire was designed to assess these mentors' leadership competencies: (1) the competence to create and strengthen cooperation culture with the aim to achieve better results of students as well as improvement of an educator; (2) the competence to find 
newest scientific research, knowledge, and information as well as use all of this for the improvement of one's activity and students' learning; (3) the competence to search for permanent professional improvement and strengthening of professional skills; (4) the competence of improvement of teaching and students' learning; (5) the competence of knowledge in the area of various assessment methods and their application; (6) the competence of cooperation with students' families and community; (7) the competence of increasing of authority of teacher's profession.

To assess these 7 competencies totally 55 questions were used. These questions were formulated using the description of each competence in the Teacher Leader Model Standard. Separated subscales were used to assess each competence. Reliability analysis was applied to evaluate the reliability of every subscale. Thus, Cronbach's alpha of the rating subscales of leadership expression ranges from 0.740 to 0.947. Cronbach's alpha of the whole rating scale of mentors leadership expression is 0.975. As Cronbach's alpha of the questionnaire and separate its parts is $>0.7$ the whole scale and subscales are evaluated as reliable.

The questionnaire for students was design for the assessment of respondents' attitude to the activity of their mentors. In order to determine how students who have participated in the research evaluated their practice mentor's activity, the Multidimensional Mentoring Measure, developed by T. A. Scandura and B. R. Ragins (1993), was used. This instrument was designed using the classical model of mentor's functions (Scandura, 1992; Scandura, Ragins, 1993). The measure has 15 items, and is comprised of three subscales measuring three dimensions: career support, psychosocial support, and role modelling. Reliability analysis was applied again to evaluate the reliability of every subscale. Thus, Cronbach's alpha of the rating subscales of leadership expression ranges from 0.820 to 0.904 . Cronbach's alpha of the whole rating scale of mentors leadership expression is 0.930. As Cronbach's alpha of the questionnaire and separate its parts is $>0.7$ the whole scale and subscales are evaluated as reliable.

To analyse the obtained data correlation analysis was applied.

\section{Results and findings}

It was determined average strong (0.622), statistically significant (0.000) linear positive correlation between mentor's leadership competences and the quality of mentor's functions performed. This correlation means that if mentor has stronger leadership competences, he or she performs mentor's functions better.

The results of further analysis show average strong, statistically significant and linear positive correlation between mentor's leadership competences and all the three dimensions of mentor's functions (see Table 
1). This correlation means that the stronger mentor's leadership competences are the better he or she performs every mentor's function.

Table 1. The correlation between mentor's leadership competences and the dimensions of mentor's functions

\begin{tabular}{|c|c|c|}
\hline $\begin{array}{c}\text { The correlation between mentor's leadership } \\
\text { competences and... }\end{array}$ & r & p \\
\hline 1. Function of career support & 0.627 & $\mathbf{0 . 0 0 0}$ \\
\hline 2. Function of psychosocial support & 0.492 & $\mathbf{0 . 0 0 0}$ \\
\hline 3. Function of role modelling & 0.594 & $\mathbf{0 . 0 0 0}$ \\
\hline
\end{tabular}

The following sections discuss the correlation between each dimension of mentor's functions and leadership competencies.

\section{The correlation between mentor's function of career support and mentor's leadership competencies}

It was determined average strong, statistically significant linear positive correlation between mentor's function of career support and leadership competences. This correlation means that if mentor has stronger leadership competences, he or she efforts to strengthen student's professional skills and professional development stronger.

When analysing the correlation between the function of career support and single leadership competences, the results show average strong, statistically significant and linear positive correlation between all the leadership competences and the function of carrier support (see Table 2). However, the strongest correlation is between function of carrier support and the competence of improvement of teaching and students' learning $(\mathrm{r}=$ $0.640 ; p=0.000)$ and the competence of increasing of authority of teacher's profession $(r=0.606 ; \mathrm{p}=0.000)$.

Table 2. The correlation between mentor's function of career support performance and leadership competences

\begin{tabular}{|c|c|c|}
\hline $\begin{array}{l}\text { The correlation between mentor's function of career support } \\
\text { and... }\end{array}$ & $\mathbf{r}$ & $\mathbf{p}$ \\
\hline $\begin{array}{l}\text { 1. The competence to create and strengthen cooperation culture } \\
\text { with the aim to achieve better results of students as well as } \\
\text { improvement of an educator }\end{array}$ & 0.516 & 0.000 \\
\hline $\begin{array}{l}\text { 2. The competence to find newest scientific research, knowledge, } \\
\text { and information as well as use all of this for the improvement of } \\
\text { one's activity and students' learning }\end{array}$ & 0.587 & 0.000 \\
\hline $\begin{array}{l}\text { 3. The competence to search for permanent professional } \\
\text { improvement and strengthening of professional skills }\end{array}$ & 0.589 & 0.000 \\
\hline $\begin{array}{l}\text { 4. The competence of improvement of teaching and students' } \\
\text { learning }\end{array}$ & 0.640 & 0.000 \\
\hline $\begin{array}{l}\text { 5. The competence of knowledge in the area of various } \\
\text { assessment methods and their application }\end{array}$ & 0.534 & 0.000 \\
\hline $\begin{array}{l}\text { 6. The competence of cooperation with students' families and } \\
\text { community }\end{array}$ & 0.469 & 0.000 \\
\hline $\begin{array}{l}\text { 7. The competence of increasing of authority of teacher's } \\
\text { profession }\end{array}$ & 0.606 & 0.000 \\
\hline
\end{tabular}




\section{The correlation between mentor's function of psychosocial support and mentor's leadership competencies.}

It was determined average strong, statistically significant linear positive correlation between mentor's function of psychosocial support and leadership competences. This correlation means that if mentor has stronger leadership competences, he or she emphasizes student's personal development and encourages student to seek for it stronger.

When analysing the correlation between the function of psychosocial support and single leadership competences, the results show average strong, statistically significant and linear positive correlation between all the leadership competences and the function of psychosocial support (see Table 3). However, the strongest correlation is between function of psychosocial support and the competence to find newest scientific research, knowledge, and information as well as use all of this for the improvement of one's activity and students' learning $(r=0.471 ; p=0.000)$ and the competence of increasing of authority of teacher's profession $(r=0.496 ; p=0.000)$.

Table 3. The correlation between mentor's function of psychosocial support and leadership competences

\begin{tabular}{|l|l|l|}
\hline $\begin{array}{l}\text { The correlation between mentor's function of } \\
\text { psychosocial support and... }\end{array}$ & $\mathbf{P}$ \\
\hline $\begin{array}{l}\text { 1. The competence to create and strengthen cooperation } \\
\text { culture with the aim to achieve better results of students as } \\
\text { well as improvement of an educator }\end{array}$ & 0.444 & $\mathbf{0 . 0 0 0}$ \\
\hline $\begin{array}{l}\text { 2. The competence to find newest scientific research, } \\
\text { knowledge, and information as well as use all of this for } \\
\text { the improvement of one's activity and students' learning }\end{array}$ & 0.471 & $\mathbf{0 . 0 0 0}$ \\
\hline $\begin{array}{l}\text { 3. The competence to search for permanent professional } \\
\text { improvement and strengthening of professional skills }\end{array}$ & 0.425 & $\mathbf{0 . 0 0 0}$ \\
\hline $\begin{array}{l}\text { 4. The competence of improvement of teaching and } \\
\text { students' learning }\end{array}$ & 0.430 & $\mathbf{0 . 0 0 0}$ \\
\hline $\begin{array}{l}\text { 5. The competence of knowledge in the area of various } \\
\text { assessment methods and their application }\end{array}$ & 0.402 & $\mathbf{0 . 0 0 0}$ \\
\hline $\begin{array}{l}\text { 6. The competence of cooperation with students' families } \\
\text { and community }\end{array}$ & 0.422 & $\mathbf{0 . 0 0 0}$ \\
\hline $\begin{array}{l}\text { 7. The competence of increasing of authority of teacher's } \\
\text { profession }\end{array}$ & 0.496 & $\mathbf{0 . 0 0 0}$ \\
\hline
\end{tabular}

\section{The correlation between mentor's function of role modelling and mentor's leadership competencies.}

It was determined average strong, statistically significant linear positive correlation between mentor's function of role modelling and leadership competences. This correlation means that if mentor has stronger leadership competences, he or she encourages mentee to identify his or her professional roles and motivates to develop professional roles stronger. 
When analysing the correlation between the function of role modelling and single leadership competences, the results show average strong, statistically significant and linear positive correlation between all the leadership competences and the function of role modelling (see Table 4). However, the strongest correlation is between function of role modelling and the competence of improvement of teaching and students' learning ( $\mathrm{r}=$ $0.618 ; \mathrm{p}=0.000$ ) and the competence of knowledge in the area of various assessment methods and their application $(r=0.580 ; p=0.000)$.

Table 4. The correlation between mentor's function of role modelling and leadership competences

\begin{tabular}{|c|c|c|}
\hline $\begin{array}{c}\text { The correlation between mentor's function of role } \\
\text { modelling and... }\end{array}$ & $\mathbf{r}$ & $\mathbf{p}$ \\
\hline $\begin{array}{l}\text { 1. The competence to create and strengthen cooperation } \\
\text { culture with the aim to achieve better results of students as } \\
\text { well as improvement of an educator }\end{array}$ & 0.573 & 0.000 \\
\hline $\begin{array}{l}\text { 2. The competence to find newest scientific research, } \\
\text { knowledge, and information as well as use all of this for } \\
\text { the improvement of one's activity and students' learning }\end{array}$ & 0.558 & 0.000 \\
\hline $\begin{array}{l}\text { 3. The competence to search for permanent professional } \\
\text { improvement and strengthening of professional skills }\end{array}$ & 0.572 & 0.000 \\
\hline $\begin{array}{l}\text { 4. The competence of improvement of teaching and } \\
\text { students' learning }\end{array}$ & 0.618 & 0.000 \\
\hline $\begin{array}{l}\text { 5. The competence of knowledge in the area of various } \\
\text { assessment methods and their application }\end{array}$ & 0.580 & 0.000 \\
\hline $\begin{array}{l}\text { 6. The competence of cooperation with students' families } \\
\text { and community }\end{array}$ & 0.496 & 0.000 \\
\hline $\begin{array}{l}\text { 7. The competence of increasing of authority of teacher's } \\
\text { profession }\end{array}$ & 0.527 & 0.000 \\
\hline
\end{tabular}

\section{To sum it up:}

- $\quad$ Mentor who supervise student during the study practice monitors mentee's activities, chose education styles, professional and personal behaviour, transfer professional experience and knowledge, tries shapes student's attitude toward the profession, rights, duties and responsibilities.

- $\quad$ Mentor's leadership competencies have an effect on performance of mentor's functions, i.e. it was determined that if mentor has stronger leadership competences, he or she performs mentor's functions better.

- $\quad$ The function of carrier support correlates with the competence of improvement of teaching and students' learning and the competence of increasing of authority of teacher's profession stronger.

- The function of psychosocial support correlates with the competence to find newest scientific research, knowledge, and information as well as use all of this for the improvement of one's activity and students' learning and the competence of increasing of authority of teacher's profession stronger. 
- $\quad$ The function of role modelling correlates with the competence of improvement of teaching and students' learning and the competence of knowledge in the area of various assessment methods and their application.

- $\quad$ The results of the research are consistent with the insights of many authors, who emphasize the importance of the mentor and mentorship, and complement the knowledge and also pay contribution to the contemporary theories of mentorship and leadership competencies.

Due to the insights occurred from the research results it becomes possible to form several recommendations:

- Higher schools should create and maintain relations with the institutions providing practice for students based on partnership. By sharing positive experience, knowledge, and expectations students, practice supervisors at higher schools and mentors create appropriate conditions and environment for the successful education of competencies, including leadership ones.

- $\quad$ This research provides background and actualises the necessity and importance of qualitative training of mentors. Since mentors having sufficient knowledge in leadership theory and practice are able to notice faster the potential of a mentee and could reveal it better. That is why qualitative training of mentors not only could help to improve the current generation of professionals, not only convey the idea of leadership, but also influence greatly the process of education and professional development of a new generation of professionals.

\section{References:}

Alerd, G., Garvey, B., Smith, R. (2000). The mentoring pocketbook. Alresford: Management pocketbooks Ltd.

Astin, A. W., Astin, H. S., and associates. (2000). Leadership reconsidered: Engaging higher education in social change. Battle Creek, MI: W. K. Kellogg Foundation.

Barkauskaitė, M., Pečiuliauskienè, P. (2007). VPU studentų pedagoginių kompetencijų raiška švietimo kaitoje. Pedagogika, T. 85, p. 43-52.

Benson, P., Saito, R. (2000). The scientific foundations of youth development. Minneapolis: Search Institute.

Brungardt, C., Greenleaf, J., Brungardt, C., Arensdorf, J. (2006). Majoring in Leadership: A Review of Undergraduate Leadership Degree Programs. Journal of Leadership Education, Vol. 5, Iss. 1, p. 4-25.

Clutterbuck D. (2004). Mentor competences: A field perspective. In Ed. by D. Clutterbuck, G. Lane, The situational mentor: An international review of competencies and capabilities in mentoring. Aldershot: Gower Publishing Ltd, p. 42-56. 
Cress, C., Astin, H., Zimmerman-Oster, K., Burkhardt, J. (2001). Developmental outcomes of college students' involvement in leadership activities. Journal of College Student Development, No. 42(1), p. 15-26.

Cummings, J. N. (2007). Leading Group from a Distance: How to Mitigate Consequences of Geographic Dispersion. Leadership at a Distance: Research in Technologically Supported Work. Mahwah, NJ: Lawrence Erlbaum Associates, p. 33-50.

Day, D. V. (2001). Leadership development: A review in context. Leadership Quarterly, Vol. 11, No. 4, p. 581-613.

Dugan, J. P., Komives, S. R. (2007). Developing leadership capacity in college students: Findings from a national study. A Report from the MultiInstitutional Study of Leadership. College Park, MD: National Clearinghouse for Leadership Programs.

Fertman, C. I., Van Linden, J. A. (1999). Character education for developing youth leadership. Education Digest, Vol. 65. No. 4, p. 11-16.

Gehrke, N. (1991). Developing Teachers' Leadership Skills. ERIC Digest.

Girves, J.E., Zepeda, Y., Gwathmey, J. K. (2005). Mentoring in a PostAffirmative Action World. Journal of Social Issues, Vol. 61, Iss. 3, p. 449479.

Komives, S. R., Owen, J. E., Longerbeam, S, Mainella, F. C., Osteen, L. (2005). Developing a leadership identity: A grounded theory. Journal of College Student Development, Vol. 6, p. 593-611.

Ladišienè, M., Monkevičienè, O. (2007). Pradedančio dirbti pedagogo ir studento praktikanto konsultavimo ypatumai. Pedagogika, Nr. 86, p. 36-43.

Lankau, M. J., Scandura, T. A. (2002). An investigation of personal learning in mentoring relationships: Content, antecedents, and consequences. Academy of Management Journal, Vol. 45. No. 4, p. 779-790.

Lindsay, D. R., Foster, C. A., Jackson, R. J., Hassan, A. M. (2009). Leadership Education and Assessment: A Developmental Approach. Journal of Leadership Education, Vol. 8, Iss. 1, p. 163-176.

Long, S. (2002). Mentoring: A personal reflection. New Library World, Vol. 103, No. 3, p. 94-97.

Middlehurst, R. (2008). Not Enough Science or Not Enough Learning? Exploring the Gaps between Leadership Theory and Practice. Higher Education Quarterly, Vol. 62, No. 4, p 322-339.

Omatsu, G. (2012). Student Leadership Training Booklet. Educational Opportunity Program. California State University, Northridge.

Paccaud, F, Weihofen, A, Nocera, S. (2011). Public health education in Europe: old and new challenges. Public Health Reviews, Vol. 33,_p. 66-86.

Pascarella, E. T., Terenzini, P. T. (2005). How college affects students: A third decade of research. San Francisco: Jossey-Bass. 
Posner, B. Z. (2009). A Longitudinal Study Examining Changes in Students Leadership Behavior. Journal of College Student Development, Vol. 50, No. 5, P. 551-563.

Riggio, R. E., Ciulla, J., Sorenson, G. (2003). Leadership education at the undergraduate level: A liberal arts approach to leadership development. In S. E. Murphy \& R. E. Ringio (Eds.), The future of leadership development. Mahwah, NJ: Lawrence Erlbaum, p. 223-236.

Roberts, D. C. (2003). Crossing the boundaries in leadership program design. In C. Cherrey, J. J. Gardiner, \& N. Huber (Eds.), Building leadership bridges. College Park, MD: International Leadership Association. p. 137149.

Scandura, T. A., Ragins, B. R. (1993). The effects of sex and gender role orientation on mentorship in male-dominated occupations. Journal of Vocational Behavior, Vol. 43, p. 251-265.

Scandura, T. A., Tejeda, M. J., Werther, W. B., Lankau, M. J. (1996). Perspectives on mentoring. Leadership \& Organization Development Journal, Vol. 17, Iss. 3, p. 50-56.

Scandura,T. A. (1992). Mentorship and career mobility: An em-pirical investigation. Journal of Organizational Behavior, Vol. 13, p. 169-174.

Scandura, T. A. (2011). Dysfunctional Mentoring Relationships and Outcomes. Journal of Management, Vol. 37, p. 280-304.

Schwartz, M. K., Axtman, K. M., Freeman, F. H. (1998). Leadership education: A source book of courses and programs (7th ed.). Greensboro, NC: Center for Creative Leadership.

Skarbalienè, A. (2013). The problem of training of leadership competencies and its solving strategies at contemporary high school. European Scientific Journal, Vol. 9, No. 14, p. 21-28.

Skarbalienè, A. (2015). The Leadership Competencies of Teachers Mentors as a Factor of Education of Leadership Competencies in Students. Doctoral dissertation. Klaipèda: Klaipèda University.

Stankevičienè, K., Monkevičienė, O. (2007). Mokymo praktikos vadyba: mentoriavimo kompetencijos. Pedagogika, Nr. 85, p. 61-67.

Šernas, V. (2005). Sintezuotas šiuolaikinių studijų modelis. Pedagogika, Nr. 78, p. 5-9.

Thibodeaux, H.E., Hays-Thomas, R. (2005). The concepts of leader-member exchange and mentoring: Core and context. Global Organizing Designs, In G. B.Graen, J. A.Graen. Greenwich, Connecticut: Information Age Publishing, p. 99-130.

Uno, H, Zakariasen, K. (2010). Public health leadership education in North America. Journal of Healthcare Leadership, Nr. 2, p. 11-15.

Van, A. J. (2002). Community college mentoring program mentor - mentee handbook. US: Iowa State University. 
Wells, C. M., Maxfield, C. R. (2010). Preparing superintendents for building teacher leadership: Implications for university programs. The International Journal of Educational Leadership preparation, No. 2, p. 1-10.

Yahner R., Lynne Goodstein (2012). Graduate student mentoring: be more than an advisor. The Pennsylvania State University. <http://www.gradsch.psu.edu/facstaff/practices/mentoring.html.>

Zimmerman-Oster, K., Burkhardt, J. (1999). Leadership in the making: Impact and insights from leadership development programs in U.S. colleges and universities. Battle Creek, MI: W. K. Kellogg Foundation. 